\title{
Policy Reform and Fathers' Use of Parental Leave in Germany: The Role of Education and Workplace Characteristics
}

\begin{abstract}
The introduction of the parental leave benefit scheme in 2007 is widely regarded as a landmark reform that has shifted the German welfare state toward a model that is more supportive to the compatibility of work and family life. In this paper, we investigate whether and how this reform has affected men's use of parental leave based on data from the German microcensus 1999-2012. We find that parental leave usage has increased across all educational levels, but the shift has been strongest for university-educated fathers. Public sector employment is beneficial for men's uptake of leave, while self-employment and temporary work lowers fathers' chances of taking leave. The parental leave reform has not affected these associations much.
\end{abstract}

Keywords: Fathers’ Involvement, Germany, Parental Leave, Parental Leave Benefit Reform, Family Policies 


\section{Introduction}

Supporting gender equality and the equal participation of men and women in the labour market is a recurrent theme in the agenda of the European Union Commission of the European Communities (2005). It is, however, also clear that European governments have been largely concerned with increasing women's labour market participation through measures such as the expansion of public child care, while policies that support a more equal division of household labour and that push men to take on childrearing obligations have not been adopted with the same enthusiasm. Only a few countries-notably, the Scandinavian countries-have a tradition of implementing policies that exert more direct influence on the involvement of fathers in childrearing. These policies include the creation of parental leave schemes with high income replacement rates coupled with proactive measures such as the so-called “paternity quota” (Sundström \& Duvander, 2002).

In 2007, Germany followed the Swedish example by enacting a radically new parental leave benefit scheme. The old parental leave benefit system, which included a monthly flat rate benefit of only $€ 300$, had been held responsible for the persistence of traditional employment patterns and regressive gender role behaviours among mothers and fathers in Germany (Gangl \& Ziefle, 2009; Ondrich, Spieß, \& Yang, 1996). This system was abolished and was replaced with a system that was modelled on the Swedish system (Erler, 2009; Spieß \& Wrohlich, 2008). The new system grants parents $65-67 \%$ of their previous net income, and includes particular incentives (frequently labelled “daddy months" or "paternity quotas”) for couples to share parental leave. The new regulations were seen as representing a radical shift in

German family policies (Henninger, Wimbauer, \& Dombrowski, 2008; Leitner, 
Ostner, \& Schratzenstaller, 2003; Spieß \& Wrohlich, 2008). After long being described in cross-national comparisons as having a conservative welfare state regime (Esping-Andersen, 1999), Germany seems to have veered off its "established policy path” (Fleckenstein, 2011, p. 546). For many observers, it is still a puzzle that this landmark reform was enacted under the leadership of a family minister from the Christian-Democratic Party. Demographic concerns, and particularly Germany’s record-low birth rates, appear to have motivated conservative policy-makers to undertake this reform. Nevertheless, increasing maternal employment and providing incentives for fathers to use parental leave were also cited as primary objectives in the reform bill (Deutscher Bundestag, 2006, p. 2).

Since the enactment of this reform, several attempts have been made to evaluate its impact on the demographic and employment behaviour of men and women in Germany. In fact, the German Family Ministry commissioned an evaluation of the reform (BMFSFJ, 2008, 2009). A major conclusion from these investigations has been that maternal employment rates have risen in response to the reform (BMFSFJ, 2014; Kluve \& Tamm, 2013; Reimer, 2013; Wrohlich, Geyer, \& Haan, 2015). While the effect of the reform on maternal employment is largely undisputed, there is conflicting evidence on the effect of the reform on birth dynamics. (Western) Germany’s total fertility rate has remained rather stable at around 1.3-1.4 children per women for decades, but increased to 1.5 children in 2015 . The recent increase could suggest a belated impact of the reform, but no firm evaluations of the effect of the parental leave benefit reform on fertility has been undertaken so far. The most significant shift seems to have occurred with respect to the behaviour of fathers. According to official statistics, the percentage of fathers among all benefit recipients has risen sharply, from less than five per cent before the reform to 26 per cent in 2014 
(Statistisches Bundesamt, 2017a). Among the children who were born in 2014, more than a third had a father who received parental leave benefit (Statistisches Bundesamt, 2017c).

Recently, several quantitative studies have been conducted that also provide us with information about the socio-demographic characteristics of the fathers who are using leave (BMFSFJ, 2008; Reich, 2010; Trappe, 2013). These studies have reported that highly educated men are more likely than less educated men to use their parental leave entitlement. In addition, workplace characteristics — and particularly having a stable public sector position-have also been shown to play a role in fathers' leavetaking decisions (Pfahl \& Reuyß, 2009). However, up to now there have been no representative studies that have compared fathers' behaviour before and after the reform. Thus, the question of whether all population subgroups have reacted similarly to this reform, or whether particular groups have been more responsive than others, has remained unanswered. In this paper, we seek to close this research gap. We do so by extending prior research that was conducted with microcensus data and investigated the role of fathers' education and the relative education of the partners in parental leave usage before the reform (Geisler \& Kreyenfeld, 2011). This prior study examined whether highly educated men, who are generally assumed to be vanguards of involved fatherhood, would also be more likely to take leave than less educated men. The study did not find support for this claim which was explained by the high earning potential of highly educated men which "seems to draw them back into the labour market and away from being an 'involved father'” (Geisler \& Kreyenfeld 2011: 96). In this paper, we expand these prior investigations and examine whether the parental leave reform of 2007 has resulted in a shift in the behaviour of highly educated men. Furthermore, we examine the role of workplace characteristics in 
parental leave usage. Here, we particularly examine whether fathers in stable public sector employment and with permanent working contracts profited more strongly from the reform than fathers in the private sector or on temporary contracts.

\section{The German Parental Leave System}

West Germany introduced its parental leave system in $1986 .{ }^{1}$ Since its inception, both fathers and mothers have been entitled to take leave. The duration of parental leave was initially limited to a maximum duration of 10 months, and parental leave benefits were paid at a flat rate of DM600 (€307). ${ }^{2}$ Persons who could not use parental leave because they were unemployed or not in the labour force were also entitled to the Between 1979 and 1985, paid maternal leave was granted for working mothers for the period of six months after birth. During this time, only mothers were entitled to a benefit equivalent to their previous net income (with a ceiling of DM750 until 1983 and DM510 since then). East Germany introduced the "Babyjahr” in 1976 which was a year-long leave with a benefit equal to the level of sickness benefits. East German regulations granted only mothers the right to take the leave. Fathers were only eligible under certain circumstances. DM600 (€307 until 2003/ €300 from 2004-2006) per month and has never been adjusted for inflation. In order to put this into perceptive: Gross monthly earnings of a full-time employed industrial worker were around DM3,223 (€1,648) in 1986 (Statitisches Bundesamt, 1988, p. 484). In 2006, monthly earnings for the same group of men were about $€ 2,670$ (Statistisches Bundesamt, 2007, p. 520). 
same amount of benefit. High income earners were not or only partially eligible for the benefit if their income exceeded certain thresholds. ${ }^{3}$

Since its introduction, the period of leave has been extended bit by bit. The first significant change in regulations was enacted in 1992, when the parental leave period was extended from 18 to 36 months. Germany thus had among the most generous parental leave entitlements in Europe at that time (Ray, Gornick, \& Schmitt, 2010). With the extension of parental leave to 36 months, the duration of the parental leave entitlement and the duration of parental leave benefits no longer matched, as the benefit payments had not been extended to 36 months (see Table A1 for an overview of the parental leave regulations).

The next major reform in 2001 introduced greater flexibility into the parental leave system as fathers and mothers were allowed to use parental leave simultaneously for the first time. Furthermore, parental leave was no longer restricted to parents with a child under age three, as parents were given the option of taking the maximum duration of three years of leave over the first eight years of the child's life. In addition, the benefit of $€ 300$ per month could be increased to $€ 450$ if only 12 months of leave were taken. Although these new regulations provided parents with greater flexibility, the low benefit and the long duration of leave were increasingly seen as an ineffective tool for fostering women's labour market integration and fathers'

3 Couples whose annual net income exceeded DM29,400 (€15,031) were only eligible for the first six months of the benefit (Bundeserziehungsgeldgesetz 06-12-1985, §5). This regulation was tightened over time. Starting in 2001, for example, couples whose yearly net income exceeded $€ 51,130$ were not eligible at all. Couples whose net income exceeded $€ 16,470$ were only eligible for six months (Neufassung Bundeserziehungsgeldgesetz, 7-02-2001, § 5). However, if the recipient was not employed during parental leave his/her income was disregarded. 
involvement with their young children (Budig, Misra, \& Boeckmann, 2012). Many observers argued that the 2001 reform, which also included a renaming of the parental leave entitlement from "Erziehungsurlaub" (parental vacation) to "Elternzeit" (parental time) was a semantic shift rather than a serious policy reform (Bothfeld, 2005, p. 14).

Unlike these previous family policy adjustments, the parental leave benefit reform, enacted January 1, 2007, must be characterized as a landmark change. Most importantly, the reform included a radical change of the parental leave benefit system. Instead of receiving a flat rate benefit of $€ 300$, parents were granted 67 per cent of their prior net income while on leave. Compared to the Swedish role model, the German system is less generous. With 65-67 per cent of prior income, Germany provides a much lower income replacement than Sweden, which grants 80 per cent. ${ }^{4}$ Furthermore, the German system includes an income cap for people who earn more than $€ 2,700$ per month, while benefits are topped-up for low-income earners. ${ }^{5}$ Nevertheless, under the revised system parental leave benefits come much closer to replacing the parent's income while on leave than under the previous system. While the parental leave duration (up to three years of parental leave) was left unchanged

4 In 2011, the replacement rate was reduced on a sliding scale to only $65 \%$ if the net monthly income exceeds $€ 1,200$. In addition, people with an annual household net income of more than $€ 250,000$ are not eligible for parental leave benefits (Bundeselterngeldgesetz 05-12-2006, §1, 2).

5 Parental leave payments are capped at $€ 1800$ per month. For low income earners (below €1000), parental leave benefits are topped up and can reach 100\% of their prior income. Parents who are not employed (unemployed, not in the labor force, in education) are entitled to a benefit of $€ 300$. This was the same monthly payment as prior to the parental leave benefit reform; however, the maximum duration of payment was shortened from 24 to 12 months. 
under the new regulations, the length of time during which the parental leave benefit could be collected was shortened: i.e., whereas previously the parental leave benefit could be collected for 24 months, the maximum duration was now 14 months. Two months of the leave benefit were reserved for each parent ${ }^{6}$ and would be lost if they were not used. This so-called "paternity quota"-which was occasionally ridiculed as the "Wickelvolontariat" (diaper-changing internship) in the German press-created the most direct incentive for fathers to use leave.

\section{Hypotheses: Differential Response to Policy Change}

As a result of the parental leave benefit reform of 2007, Germany moved away from having a flat-rate benefit system toward having an earnings-related benefit system. This policy shift has obviously altered the economic incentives for parents to take parental leave. Apart from unemployed men (who are not included in our investigation), all groups have seen an increase in the absolute amount of parental leave benefits. In addition, the "daddy months" create an additional incentive for fathers to take leave. All else being equal, one would assume that the probability of parental leave uptake has increased for all men after the reform (ypothesis 1).

Highly educated are generally assumed to be more likely to earn higher wages. As the parental leave benefits are now earnings-related, highly educated seem to have profited most from the reform. They may temporarily withdraw from the labour market and still receive a decent household income. Economic theory tells us, however, that decisions of this kind are not based on the absolute amount of benefits. Instead, the transfers during parental leave are weighted against the foregone income

6 Single parents are entitled to 14 months of the benefit. 
and career opportunities in the labour market. Highly educated men face higher opportunity costs for taking leave than less educated men because of the higher income that is associated with more education. As higher earners usually pursue career tracks that are more sensitive to career interruptions, the opportunity costs of foregone income are also higher for this group of men. With the reform, the opportunity costs for using parental leave declined for all groups. However, highincome earners benefited less in relative terms. The parental leave benefit covers only 65-67 per cent of prior net income. Further, benefits are cut for men with a net monthly income of more than €2,700. Conversely, payments for men with a net income of less than $€ 1,000$ are topped up and the parental leave benefits may greatly exceed 67 per cent of prior income. As education and income are closely correlated, we would assume that a negative educational gradient not only persisted, but may have even become steeper after the reform (ㅂypothesis 2a).

An alternative sociological view suggests that parental employment decisions are not influenced by economic determinants alone; instead, they are embedded in cultural and moral norms of appropriate behaviour for parents (Duncan, et. al. 2003). People make "care decisions" based on moral and socially negotiated views about proper behaviour, and these views vary by population subgroups. Less educated men are usually assumed to adhere to traditional gender roles, while the highly educated are seen as being at the forefront of a trend toward the greater involvement of fathers in childrearing (Juby \& Le Bourdais, 1998; Sayer, Gauthier, \& Furstenberg, 2004). However, they often fail to live up to these ideals as their high earnings pull them into employment and into the role of the male breadwinner (Kaufman \& Uhlenberg, 2000). The new parental leave benefit scheme does not provide full income replacement, but it allows men to temporarily step back from the role of a 
breadwinner and lessens the tension between their ideals of involved fatherhood and the continued need to provide enough income to support the family. Against that background, we assume that highly educated men are more likely to embrace the new opportunities compared to less educated men. As a result, highly educated men are expected to have changed their behaviour more strongly following the implementation of the parental leave benefit reform than less educated men (ㅂypothesis $2 \mathrm{~b})$.

Employment decisions are not made in isolation, but in the household context. A standard assumption is that the person in the household who can expect the higher labour market earnings is the most likely to work, while the other takes care of the child or the children. As education and income are closely related, we expect that men are more likely to take leave in cases in which they are less educated than their partners. Conversely, men who are more highly educated than their partners should be less likely to take leave. However, the contrasting, abovementioned argument about highly educated men being vanguards of modern gender role attitudes could also extend to an analysis that examines women and men's combined education. Highly educated men who are partnered with less educated women might have wanted to use leave but have had little leeway under the old system to act as involved fathers, because they need to provide for the household income. The newly introduced income-related benefit enables these fathers to step back from that role for a certain time to care for their children. Thus, we expect to see the highest increase in the probability to use parental leave after the reform among men with partners who are less educated than themselves (

Apart from education, workplace characteristics are important determinants of whether a father takes leave. Although all employees, regardless of their job status, have the right to use parental leave, men in more precarious or atypical employment 
situations might be more reluctant to ask for leave. Fathers on temporary contracts may be worried that leave-taking may be regarded as a negative signal to the employer so that their working contract would not be renewed if they took leave. Selfemployed fathers might also be reluctant to make use of that option as they may fear losing their clients during leave. In general, the new regulations are primarily concerned with the details of income replacement but did not include any regulations that would have strengthened the rights of workers in precarious employment. After all, the regulations were targeted at workers with standard working contracts who are able to interrupt their employment after childbirth. Against this background, we assume that men on permanent contracts have been more likely than other men to take advantage of the new parental leave regulations (Hypothesis 4).

Compared to the private sector, public sector employment is usually more conducive to the compatibility of family and work. The high prevalence of collective agreements provides a higher degree of job protection. Wages are usually set by collective wage agreements and are thus less subject to individual performance and negotiations. In addition, the public sector is usually non-profit so that a production loss due to the absence of an employee might be more accepted than in private companies (Bygren \& Duvander, 2006, p. 365). Further, employees’ rights may be guarded to a higher degree in the public sector, as work councils are more established there than in private firms. Finally, part of the public sector employees are employed as civil servants (Beamte) who benefit from a privileged system of a right to life-long employment. Against this background, one would expect to find men who work in the public sector to be more likely to take parental leave than fathers who are employed in the private sector. It is less clear whether this association has strengthened after the reform. On the one hand, both private and public sector employees profited from the 
reform as they both were subject to the same level of income replacement. On the other hand, private sector employees may have been reluctant to make use of the new options, as they may still fear that leave-taking is not accepted in their firms or that it may eventually be harmful for their career development. Against that background, we expect that public sector employees were more eager to embrace the new opportunities and took more leave after the reform (ㅂypothesis 5).

\section{Prior Studies on Fathers' Parental Leave Usage}

The German parental leave system was largely copied from the Swedish system. The Nordic countries were, however, not only pioneers in the introduction of parental leave benefit schemes, but the large amounts of register data made available by these countries have greatly advanced empirical research in this area. Several studies for the Nordic countries have found that better educated men are more likely than less educated men to use parental leave (Lappegard, 2008; Sundström \& Duvander, 2002). However, Sundström and Duvander (2002) only found a positive effect of men's education when earnings were controlled for, and Bygren and Duvander (2006) reported no association between fathers' education and the use of parental leave. It has also been shown that fathers with highly educated female partners are more likely to use parental leave than other fathers (Bygren \& Duvander 2006; Duvander \& Johansson 2010; Haas, Allard \& Hwang 2002; Lappegard 2008). There are only few studies that investigated the effect of the relative education of the partners and the evidence is mixed. While Naz (2010) reported that men are more likely to take leave if their female partners have the same or a higher level of education, other studies found no differences (Duvander \& Johansson 2010; Lammi-Taskula 2008). There is 
consistent evidence that whether fathers use leave is heavily influenced by their type of occupation and the characteristics of their workplace (Bygren \& Duvander, 2006; Haas, Allard, \& Hwang, 2002; Naz, 2010). Bygren and Duvander (2006) showed that fathers who work in the public sector or in a larger company are more likely to use parental leave than fathers in the private sector or in a small company. Using Swedish survey data, Haas, Allard, and Hwang (2002) found that the organizational culture of a company is another vital factor in men's parental leave usage. They showed that the perceived norms regarding overtime as well as the level of support from management greatly influence men’s decisions about whether to take leave.

Studies for Sweden that have examined the effects of policy changes on men's behaviour have found consistent evidence that fathers' usage of parental leave increased after the implementation of the paternity quota in that country (Björnberg, 2002; Duvander \& Johansson, 2012). However, there is some dispute over how substantial and how durable the effect of the paternity quota has been. Duvander and Johansson (2012) compared the long- and short-term effects of the paternity quota in 1995, and again in 2002 following the extension of the quota from one to two months. They further investigated the effectiveness of the gender equality bonus, introduced in 2008, which provides tax credits for couples who share their parental leave equally. They found that the initial introduction of the paternity quota had the most pervasive influence on fathers' use of leave, while the extension of the quota had a smaller effect. Their results further showed that the introduction of the gender equality bonus did not lead to any significant behavioural changes. Duvander and Johansson (2010) also investigated how different population subgroups responded to policy changes. They found that fathers with tertiary education were more likely to take leave than fathers with lower levels of education after the introduction of the paternity quota, and 
identified a similar pattern for the gender equality bonus. However, they did not find that highly educated fathers responded differently than other fathers when the paternity quota was extended from one to two months.

Until recently, there were very few studies for Germany on men's use of parental leave. The few studies that existed were based on the results of qualitative interviews or attitudinal surveys that asked men, women and employers for their opinions regarding parental leave usage by fathers (Beckmann, 2001a, 2001b; Institut für Demoskopie Allensbach, 2005; Vaskovics \& Rost, 1999). But following the reform of the parental leave benefit system, research in this area increased in tandem with the growing share of fathers using leave. A study commissioned by the Family Ministry (BMFSFJ, 2008) that investigated the behaviour of the fathers of children born in 2007 found that the men's educational level had a positive effect on their likelihood of taking parental leave. Using data from the German microcensus 2008, Reich (2010) reported that less educated as well as highly educated men had elevated chances of taking leave. Trappe (2013) investigated the effects of the couples' education on the likelihood that the man would take leave, and found that the chances were strongly elevated when both partners were highly educated. Based on register data from two German states, she also examined the effect of earnings on the length of parental leave taken by the fathers of children born in 2007-2009. A finding is here that fathers who had a low income or who earned less than their female partners were especially likely to take a longer period of leave. A non-representative online survey by Pull and Vogt (2010) reported that earnings differences between the man and the woman are a good predictor of whether a father will take leave, but that these differences have no significant impact on the duration of leave. They also found that men who were better educated than their partners were less likely to use parental leave. There are only a 
few large-scale representative studies for Germany that have examined the effects of workplace characteristics on leave-taking behaviour. Geisler and Kreyenfeld (2011), who examined the period before the reform, reported that being in public sector employment increases the likelihood that a father will take leave. This finding is in line with the results of a study by Pfahl and Reuyß (2009) in which they analysed the attitudes and experiences of men who took parental leave. A recent opinion survey has also confirmed that concerns about income loss and career setbacks are still the main barriers to fathers’ leave-taking (Institut für Demoskopie Allensbach, 2015, p. 26). Although significant empirical evidence has amassed showing how fathers' education and workplace characteristics influence fathers' leave taking, none of the abovementioned studies for Germany has examined how patterns have shifted with the policy reform.

\section{Data, Variables, and Methods}

The data for this analysis come from the German microcensus which is a one per cent sample of the population living in Germany. We restricted the analysis to data from the years 1999 to 2012 because earlier microcensuses did not include precise information on the use of parental leave, and later microcensuses are not yet available. We further restricted the analysis to men between the ages of 18 and 55 who had a child under age three who was living in the same family unit. In principle, it is possible to use parental leave until the child's eighth birthday; however, relatively few parents use the leave when the child is older than age three. We also excluded unemployed and inactive fathers from our sample. This may be seen as a drawback because the inactive and unemployed fathers are the only ones who did not see an 
increase in parental leave benefit payments after the reform. However, our focus is on parental leave usage. Under the benefit scheme, unemployed and inactive fathers are eligible to receive parental leave benefit payments, but they are not eligible to take parental leave because they have not been working (either as an employee or as a selfemployed individual). In addition, we excluded the small number of single fathers and fathers in same-sex unions from the sample.

The total sample size consisted of 125,100 respondents. Of these respondents, 1,205 fathers, or 1 per cent of the study population, were on parental leave at the time of the interview. The fraction is higher after the reform (2\%) than before the reform $(0.5 \%)$. This can, however, not obscure that the values seem to stand in some contrast to the high shares of male parental leave benefit recipients regularly reported by the German Family Ministry. The reason for the seeming mismatch is that one of main indicators that the Statistical Office reports is the proportion of children for whom fathers have received the benefit (28\% in 2012) (Statistisches Bundesamt, 2017a, 2017b). Since our data do not provide retrospective employment information, we take a snap-shot in time and estimate the probability that a father with a child aged $0-2$ (the period parents are eligible to use leave) is taking leave at the time of the interview. There may be some fathers who have taken leave with a child, but because the time of leave was short, they might have already returned to work when the interview was conducted. Thus, our approach gives a correct account of the probability of being on parental leave at the time of the interview, but fathers with short leave durations are less likely to be captured as "leave takers” in our analysis.

We use a binary logistic regression to study the probability that a father was on leave at the time of the interview. We are unable to allocate the parental leave usage to a particular child in the family. Here we assume that the father is on leave 
with the youngest child in the household. One of the key independent variables in our analysis is the father's education (categorized into no degree (low education), vocational degree (medium education), and university degree (high education)). We furthermore generated a variable that measures relative educational levels of the two parents (categorized into both no degree, both vocational training, both university degree, woman more highly educated than partner, man more highly educated than partner). Workplace characteristics are measured with two variables: the type of sector (public or private sector) and the type of contract (temporary, permanent, selfemployed). The control variables in the model are age, child's age, number of children, region (eastern or western Germany), citizenship (German or non-German), and partnership status (married or cohabiting). Finally, a binary variable was created that indicates whether the youngest child was born before or after the enactment of the policy reform. The new parental leave benefit system came into force January 1, 2007. Our data covers the years 1999-2012. The analytical sample includes men with children ages 0-2 at time of interview. Thus, we distinguish fathers whose youngest child was born 1996-2006 from fathers whose youngest child was born 2007-2012.

[Table 1 about here]

Our analytical strategy consists of two steps. First, we investigate the determinants of parental leave usage for the entire sample. In a second step, we explore whether the role of education and workplace characteristics in leave usage have changed over time. In this part of the analysis, we present models in which we interacted our independent variables with a dummy variable that distinguishes between fathers 
whose children were born before the reform (1996-2006) and the period after the reform (2007-2012). Our key variables of interest are the father's education, the relative education of the partners, and the workplace characteristics (type of contract and type of sector).

\section{Results}

Table 2 provides the results of the first part of the analysis. While Model 1 only includes individual characteristics, Model 2 also accounts for relative education. We look first at Model 1 and its control variables. As expected (see hypothesis 1), fathers’ uptake of leave increases after the reform. The model also indicates that foreigners are less likely to be on leave than Germans and that eastern Germans are more likely to be on leave than their western German counterparts. The latter finding corresponds to the results of prior research suggesting that eastern German men adhere to more egalitarian gender role ideals than western German men (Blohm \& Walter, 2016). The model also finds a positive association between the father's age and leave usage. The child's age and the number of children are, as expected, negatively associated with leave usage. Men in non-marital unions are more likely to be on leave than fathers in marital unions. This finding contradicts the results of prior research for Scandinavian countries (Sundström and Duvander 2002), but it is in line with findings for Germany that the division of housework is more equal in non-marital than in marital unions (Lois, 2009). In line with our expectations, we find that workplace characteristics relate to fathers' leave-taking behaviour. Men on temporary contracts and the selfemployed are less likely to use parental leave, while fathers employed in the public sector have a higher probability of being on leave compared to men working in the 
private sector. Our key variable of interest is men's level of education. We do not find large differences in leave-taking by level of education. For all educational groups, the probability of being on leave at the time of the interview is around $1 \%$.

Model 2 includes the results for "relative education". For most groups, the probability of a man being on leave is far below $1 \%$. There are two groups that stand out with higher chances of leave usage. On the one hand, this is the small share of men with a partner who had more education than they did. The second group consists of men with a university education who had an equally educated partner.

[Table 2 about here]

Our main research question is whether the determinants of leave usage have changed since the introduction of the reform. In order to investigate this question, we estimate models that include an interaction term that distinguishes fathers whose youngest child was born before the reform (years 1996-2006) and those whose youngest child was born after the reform (years 2007-2012). We have chosen a graphical representation to display the results of the interaction models. Figure 1 provides the results for fathers' education. For the period 1996-2006, education and leave usage of fathers was largely unrelated. For all groups, the probability of being on leave at the time of the interview was only around $0.5 \%$. After the reform, the probability of leave-taking increases for all groups. The largest effect can, however, be found for the university educated fathers, for whom the probability increases to $2.2 \%$. As a result, we find a positive educational gradient in leave-taking after the reform. These results support the idea that the new parental leave benefit system has encouraged highly 
educated fathers in particular to take leave (see hypothesis 2b). As such, we must refute hypothesis 2a that has stated that highly educated men would also be less likely to take leave under the new system, because of the large income loss that they incur when on leave.

[Figure 1 about here]

Figure 2 presents the results for relative education. For both periods we observe a pattern similar to the pattern we saw in the initial model: i.e., men who are less educated than their female partners are more likely to take leave, while fathers who have more education than their female partners are the least likely to do so. Even after the reform, the latter group continued to be reluctant to take advantage of the leave benefits. However, we can still see that this group has changed their behaviour the most. Men who are more highly educated than their female partners are under economic pressure to act as breadwinners. Apparently, the new parental leave regulations have enabled some of these men to temporarily step back from their role as male breadwinner (see hypothesis 3).

[Figure 2 about here]

Figure 3 provides the results by type of contract. Compared to men on permanent contracts, self-employed men and men on temporary working contracts are less likely to be on parental leave. Although parental leave usage has become more common across all groups, the overall pattern has remained unchanged. Figure 4, 
which displays the results by type of sector, provides a similar picture. It shows that leave usage is more common among public sector employees, both before as well as after the reform. The relative change is the same for both groups with an increase in the probability of leave taking by about $200 \%$. This means that we have to refute hypothesis 4 and 5, which had stated that men on permanent contracts and in public sector employment would have been more likely to embrace the opportunities of the new parental leave benefit system.

[Figure 3 \& 4 about here]

\section{Summary and Discussion}

The aim of this paper was to evaluate men's responses to the parental leave benefit reform that was enacted by the German government in 2007. In particular, we examined whether subgroups of men responded to the reform differently. We found that there has been a strong overall increase in fathers' uptake of parental leave since the reform. This finding may not come as a great surprise. However, it is important to note that (West) German family policies have regularly been typified as familialistic and strongly biased towards the male breadwinner model. The features that led scholars to reach that conclusion are a system of joint taxation that heavily taxes the second earner, a childcare system that provided very limited care for small children and a population that employed the term Rabenmutter to emphasize that working women neglect their children. Against this background, some scholars viewed the new parental leave scheme as "alien" to the German system. Other considered it "premature", assuming that these policies were being imposed ahead of real 
behavioural changes (Lewis, 2001, p. 158; Lewis, Campbell, \& Huerta, 2008; Schutter \& Zerle-Elsäßer, 2012, p. 218). It could thus easily be assumed that the parental leave benefit reform would have been completely ineffective in changing behavioural patterns. The finding that parental leave usage increased for all the groups under investigation after the reform provides some evidence to refute this claim. It suggests instead that progressive family policies are able to change behavioural patterns also in conservative welfare state settings.

Our investigations also showed that the increase in parental leave usage was greatest among highly educated fathers. While there was no educational gradient in leave taking before the reform, a positive gradient emerged afterwards. Furthermore, the increase in parental leave usage was highest among the men who were better educated than their female partners. This finding is at odds with the observation that the opportunity costs of leave-taking are largest for highly educated men, who should thus be less likely to use leave. It is, however, compatible with the observation that highly educated men express more liberal gender role attitudes and a greater commitment to get involved in the upbringing of their children. Yet this group of men were previously unable to live up to their ideals because their high earning power pushed them into the role of breadwinners. Although opportunity costs of parental leave usage are still relatively higher for men with high income, the German parental leave benefit reform provides an income replacement that enabled highly educated men to partially live up to their ideals of being an involved father.

Our analysis also supports prior research that showed that workplace characteristics, sector of employment, and type of employment contract are important determinants of a father's parental leave usage. Public sector employees were more likely than private sector employees to have taken leave before the reform, and this 
gap persisted after the reform. The same applies to self-employed men and men on temporary working contracts who are still more reluctant than men on permanent contracts to take advantage of parental leave regulations. These results underline that atypical work arrangements remain a strong barrier to leave-taking. The share of employees on temporary contracts has been growing steadily in recent years, but their particular situation is generally not reflected in family policy legislations.

Although our paper provides novel evidence on how the parental leave benefit reform altered behavioural patterns in Germany, there are many caveats to be mentioned. One of the main findings is that highly educated men were those who most strongly expanded their usage of parental leave after the reform. Our interpretation of this finding is that high earnings used to push highly educated men towards the role of male breadwinners. The new system provides them the economic leeway to act according to their pronounced ideals of involved fatherhood. However, the microcensus does not survey attitudes nor does it provide suitable income data. Thus, our interpretation must be speculative as we were unable to carefully carve out the role of income and attitudes in leave-taking behaviour.

In our analysis, we examined the probability to be on leave at the time of the interview. With our data, we were unable to examine the duration of leave. We also did not investigate whether fathers had previously taken leave. Thus, our approach is rather conservative as it only captures the men who were on leave at the time of the interview. In 2012, 82 percent of fathers who received parental leave benefits used leave for three or less months (Statistisches Bundesamt, 2017a). From these data, it seems that short durations of leave are widely taken advantage of, while fathers refrain from taking long periods of leave. Because the characteristics of fathers who choose short and long durations of leave differ (Trappe, 2013), our results may 
primarily reflect the characteristics of "long leave takers" who represent a smaller group among all fathers ever having taken leave.

The introduction of the new parental leave benefit system was accompanied by a heated public debate. It is certainly possible that the public discourse triggered a process in which the societal norms that guide parental and gender role behaviour have shifted. Attitudinal surveys indicate that the proportion of people who embrace a more equal division of family responsibilities increased radically in (western) Germany between 2000 and 2012 (Blohm and Walter 2016: 428). It is also possible that the "daddy months" have incentivised fathers to take some leave while establishing a normative understanding that only short durations of paternal leave are appropriate. How societal expectations have shifted in response to the family policy reforms and how they tie into men's behavioural changes could not be addressed with our approach. It must be left to future quantitative, and particularly qualitative research, to understand the normative forces that channel fathers into short and long durations of leave-taking.

\section{References}

Beckmann, P. (2001a). Neue Väter braucht das Land! Wie stehen die Chancen für eine stärkere Beteiligung der Männer am Erziehungsurlaub? IABWerkstattbericht No. 6.

Beckmann, P. (2001b). Neue Väter braucht das Land! Wie stehen die Chancen für eine stärkere Beteiligung der Männer am Erziehungsurlaub? IAB_Werkstattbericht No. 6 .

Björnberg, U. (2002). Ideology and choice between work and care: Swedish family policy for working parents. Critical Social Policy, 22(1), 33-52.

Blohm, M., \& Walter, J. G. (2016). Einstellungen zur Rolle der Frau und der des Mannes. In Statistisches Bundesamt/WZB (Ed.), Datenreport 2016: Ein Sozialbericht für die Bundesrepublik Deutschland (pp. 426-431). Bonn.

BMFSFJ. (2008). Evaluation des Gesetzes zum Elterngeld und zur Elternzeit: Endbericht 2008. Berlin: BMFSFJ. 
BMFSFJ. (2009). Evaluationsbericht Bundeselterngeld- und Elternzeitgesetz 2009. Berlin: BMFSFJ.

BMFSFJ. (2014). Dossier Müttererwerbstätigkeit 2012. Berlin: BMFSFJ.

Bothfeld, S. (2005). Vom Erziehungsurlaub zur Elternzeit: Politisches Lernen im Reformprozess. Frankfurt/New York: Campus.

Budig, M. J., Misra, J., \& Boeckmann, I. (2012). The motherhood penalty in crossnational perspective: The importance of work-family policies and cultural attitudes. Social Politics, 19(2), 30.

Bygren, M., \& Duvander, A.-Z. (2006). Parents' workplace situation and fathers' parental leave use. Journal of Marriage and Family, 68(2), 363-372.

Commission of the European Communities. (2005). Green Paper "Confronting demographic change: A new solidarity between the generations".

Deutscher Bundestag. (2006). Gesetzentwurf der Fraktionen der CDU/CSU und SPD: Entwurf eines Gesetzes zur Einführung des Elterngeldes. Drucksache 16/1889.

Duncan, Simon; Edwards, Rosalind; Reynolds, Tracey; Alldred, Pam (2003). Motherhood, paid work and partnering: Values and theories. Work Employment and Society, 17(2): 309-330.

Duvander, A.-Z., \& Johansson, M. (2010). What are the effects of reforms promoting fathers' parental leave use? SPaDE Working Paper 9.

Duvander, A.-Z., \& Johansson, M. (2012). What are the effects of reforms promoting fathers' parental leave use? Journal of European Social Policy, 22(3), 319330.

Erler, D. (2009). Germany: Taking a Nordic turn? In S. B. Kamerman \& P. Moss (Eds.), The Politics of Parental Leave Policies (pp. 119-134). Bristol Policy Press.

Esping-Andersen, G. (1999). Social Foundations of Postindustrial Economies. Oxford: Oxford University Press.

Fleckenstein, T. (2011). The politics of ideas in welfare state transformations: Christian democracy and the reform of family policy in Germany. Social Politics, 18(4), 543-571.

Gangl, M., \& Ziefle, A. (2009). Motherhood, labor force behavior, and women's careers: An empirical assessment of the wage penalty for motherhood in Britain, Germany, and the United States. Demography, 46, 341-369.

Geisler, E., \& Kreyenfeld, M. (2011). Against all odds: Fathers' use of parental leave in Germany. Journal of European Social Policy, 21(1), 88-99.

Haas, L., Allard, K., \& Hwang, P. (2002). The impact of organizational culture on men's use of parental leave in Sweden. Community, Work \& Family, 5(3), 319-342.

Henninger, A., Wimbauer, C., \& Dombrowski, R. (2008). Demography as a push toward gender equality? Current reforms of German family policy. Social Politics, 15(3), 287-314.

Institut für Demoskopie Allensbach. (2005). Einstellungen junger Männer zu Elternzeit, Elterngeld und Familienfreundlichkeit im Betrieb. Ergebnisse einer repräsentativen Bevölkerungsumfrage. Allensbach: Institut für Demoskopie Allensbach.

Institut für Demoskopie Allensbach. (2015). Weichenstellungen für die Aufgabenteilung in Familie und Beruf: Untersuchungsbericht zu einer repräsentativen Befragung von Elternpaaren im Auftrag des BMFSFJ. http://www.ifd-allensbach.de/uploads/tx_studies/Weichenstellungen.pdf. 
Juby, H., \& Le Bourdais, C. (1998). The changing context of fatherhood in Canada: A life course analysis. Population Studies, 52(2), 163-175.

Kaufman, G., \& Uhlenberg, P. (2000). The influence of parenthood on the work effort of married men and women. Social Forces, 78(3), 931-947.

Kluve, J., \& Tamm, M. (2013). Parental leave regulations, mothers' labor force attachment and fathers' childcare involvement: evidence from a natural experiment. Journal of Population Economics, 26, 983-1005.

Lappegard, T. (2008). Changing the gender balance in caring: Fatherhood and the division of parental leave in Norway. Population Research and Policy Review, 27( 2), 139-159.

Leitner, S., Ostner, I., \& Schratzenstaller, M. (2003). Was kommt nach dem Ernährermodell? Sozialpolitik zwischen Re-Kommodifizierung und ReFamilisierung. In S. Leitner, I. Ostner, \& M. Schratzenstaller (Eds.), Wohlfahrtsstaat und Geschlechterverhältnis im Umbruch. Was kommt nach dem Ernährermodell? (Vol. 7, pp. 9-27). Wiesbaden: VS Verlag für Sozialwissenschaften.

Lewis, J. (2001). The decline of the male breadwinner model: Implications for work and care. Social Politics, 8(2), 152-169.

Lewis, J., Campbell, M., \& Huerta, C. (2008). Patterns of paid and unpaid work in Western Europe: Gender, commodification, preferences and the implications for policy. Journal of European Social Policy, 18(1), 21-37.

Lois, D. (2009). Lebensstile und Entwicklungspfade nichtehelicher Lebensgemeinschaften: Eine empirische Analyse mit dem Soziooekonomischen Panel. Wiesbaden: VS Verlag.

Naz, G. (2010). Usage of parental leave by fathers in Norway. International Journal of Sociology and Social Policy, 30(5/6), 313-325.

Ondrich, J., Spieß, C. K., \& Yang, Q. (1996). Barefoot and in a German Kitchen: Federal Parental Leave and Benefit policy and the Return to Work after Childbirth in Germany. Journal of Population Economics, 9(3), 247-266.

Pfahl, \& Reuyß. (2009). Das neue Elterngeld: Erfahrungen und betriebliche Nutzungsbedingungen von Vätern. Düsseldorf: Hans-Böckler-Stiftung.

Pull, K., \& Vogt, A.-C. (2010). Viel Lärm um Nichts? Der Einfluss der Elterngeldreform auf die Inanspruchnahme von Elternzeit durch Väter. Soziale Welt, 61(2), 121-137.

Ray, R., Gornick, J. C., \& Schmitt, J. (2010). Who cares? Assessing generosity and gender equality in parental leave policy designs in 21 countries. Journal of European Social Policy, 20(3), 196-216.

Reich, N. (2010). Predictors of fathers' use of parental leave in Germany. Population Review, 50(2), 1-22.

Reimer, T. (2013). Elterngeld: Analyse der Wirkungen. Wiesbaden: Springer VS.

Sayer, L. C., Gauthier, A. H., \& Furstenberg, F. F. (2004). Educational differences in parents' time with children: Cross-national variations. Journal of Marriage and Family, 66(5), 1152-1169.

Schutter, S., \& Zerle-Elsäßer, C. (2012). Das Elterngeld: Wahlfreiheit und Existenzsicherung für (alle) Eltern? WSI Mitteilungen 3/2012.

Spieß, C. K., \& Wrohlich, K. (2008). The parental leave benefit reform in Germany: Costs and labour market outcomes of moving towards the Nordic model Population Research and Policy Review, 27, 575-591.

Statistisches Bundesamt. (2007). Statistisches Jahrbuch für die Bundesrepublik Deutschland. Wiesbaden: Statistisches Bundesamt. 
Statistisches Bundesamt. (2017a). Elterngeldempfänger nach Geburtszeiträumen: Deutschland, Jahre, Geschlecht, Bezugsdauer des Elterngeldes. Ergebnis 22922-0009. Genesis-Online Database. https://wwwgenesis.destatis.de/genesis/online.

Statistisches Bundesamt. (2017b). Lebendgeborene: Deutschland, Jahre, Geschlecht. https://www-genesis.destatis.de/genesis/online.

Statistisches Bundesamt. (2017c). Sozialleistungen-Elterngeld: Elterngeld. Beendete Leistungsbezüge für Geburtszeiträume. Länder, Geburten, Väterbeteiligung am Elterngeld für im Jahr 2014 geborene Kinder.

https://www.destatis.de/DE/ZahlenFakten/GesellschaftStaat/Soziales/Sozialleistungen /Elterngeld/Tabellen/GeburtenVaeterbeteiligungJahr2014.html (Download 23-5-2017).

Statitisches Bundesamt. (1988). Statistisches Jahrbuch für die Bundesrepublik Deutschland (Band 1989). Wiesbaden: Statistisches Bundesamt.

Sundström, M., \& Duvander, A.-Z. E. (2002). Gender division of childcare and the sharing of parental leave among new parents in Sweden. European Sociological Review, 18(4), 433-447.

Trappe, H. (2013). Väter mit Elterngeldbezug: Nichts als ökonomisches Kalkül? Zeitschrift für Soziologie, 42(1), 28-51.

Vaskovics, L. A., \& Rost, H. (1999). Väter und Erziehungsurlaub (Vol. 179). Stuttgart: Kohlhammer.

Wrohlich, K., Geyer, J., \& Haan, P. (2015). The effects of family policy on mothers' labor supply: Combining evidence from a structural model and a quasi-experimental approach. Labour Economics, 36, 84-98. 


\section{Appendix}

Table A1: Overview of Landmark Reforms in the German Parental Leave and Parental Leave Benefit System

\begin{tabular}{|c|c|c|c|c|}
\hline Year & $\begin{array}{l}\text { Duration of } \\
\text { Leave }\end{array}$ & $\begin{array}{l}\text { Duration of } \\
\text { BenentiAmount }\end{array}$ & $\begin{array}{l}\text { Income } \\
\text { Thresholds }\end{array}$ & Flexibillity \\
\hline 1986 & Tomonthe & $\begin{array}{l}\text { 10 monthel } \\
\text { flat rate } € 307\end{array}$ & $\begin{array}{l}\text { Monthis 1-6: No threshold } \\
\text { After } 6^{\text {m}} \text { month: threshold after } \\
\text { which payment is reduced on a } \\
\text { silding scale } \\
\text { (Threshold levels E15,032 for } \\
\text { marrled; E12,118 for unmarried) } \\
\text { (Income of benent reciplent is not } \\
\text { taken Into account if sine Is not } \\
\text { employed during leave.) }\end{array}$ & $\begin{array}{l}\text { Parents can take furns in taking } \\
\text { leave once, but leave cannot be } \\
\text { taken simultaneously by both } \\
\text { parents. } \\
\text { Parn-time employment up to } 19 \\
\text { hours/week is possible. } \\
\text { Leave cannot be used if the other } \\
\text { partner ls inactive in the labour } \\
\text { market. }\end{array}$ \\
\hline 1988 & 12 monthe & $\begin{array}{l}\text { T2 monthe } \\
\text { e307 }\end{array}$ & No major change & $\begin{array}{l}\text { Pari-fime employment up to } 18 \\
\text { hours/week ls possible. }\end{array}$ \\
\hline $07 / 1989$ & 15 monthe & $\begin{array}{l}15 \text { monthel } \\
\text { e307 }\end{array}$ & No major change & $\begin{array}{l}\text { Pari-time employment up to } 19 \\
\text { hours/week is possible. }\end{array}$ \\
\hline $07 / 1990$ & 18 monthe & $\begin{array}{l}18 \text { monther } \\
\text { ध307 }\end{array}$ & No major change & No change \\
\hline 1992 & 36 months & No change & No major change & $\begin{array}{l}\text { Non-marrled tathers without custody } \\
\text { are entiled to use leave and recelve } \\
\text { parental leave benefits (with the } \\
\text { mother's approval). } \\
\text { Parents can take turns in taking } \\
\text { leave three times. }\end{array}$ \\
\hline 1993 & No change & $\begin{array}{l}24 \text { monther } \\
\text { e307 }\end{array}$ & No major change & No change \\
\hline $06 / 1993$ & No change & No change & $\begin{array}{l}\text { Threshold for unmarried couples } \\
\text { is the same as for marrled } \\
\text { couples; the partner's income is } \\
\text { now taken Into acoount. }\end{array}$ & No change \\
\hline 1994 & No change & No change & $\begin{array}{l}\text { Months 1-6: Introduction of } \\
\text { threshold levels ( } ₹ 51,129 \text { for } \\
\text { couples, } € 38,347 \text { for lone parents) } \\
\text { After } 6^{n} \text { month: No major change }\end{array}$ & No change \\
\hline 2001 & No change & $\begin{array}{l}12 \text { monthe/ } E 40^{\circ} \\
24 \text { months/ } \in 307\end{array}$ & $\begin{array}{l}\text { Months } 1-6: \epsilon 51,129 \text { for couples, } \\
\text { E38,347 for lone parents } \\
\text { After } 6^{\text {h }} \text { month: } € 16,464 \text { for } \\
\text { couples, } € 13,498 \text { for lone parents }\end{array}$ & $\begin{array}{l}12 \text { monthe of parental laave may be } \\
\text { taken up to chlld's } 8 \text { th birthday } \\
\text { (employer has to agree) } \\
\text { Parental leave and part-time } \\
\text { employment (up to } 30 \text { hours) may be } \\
\text { combined. } \\
\text { Parental leave may be taken } \\
\text { simultaneously by both parents, } \\
\text { Leave can now also be taken If the } \\
\text { other partner is inactive in the labour } \\
\text { market. }\end{array}$ \\
\hline 2000 & No change & $\begin{array}{l}12 \text { monthel } \in 450 \\
24 \text { months/ } \in 300\end{array}$ & 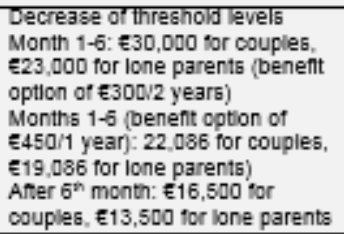 & No change \\
\hline $\begin{array}{l}2007 \\
\text { (births } \\
\text { from } \\
\text { January, 1) }\end{array}$ & No change & $\begin{array}{l}\text { 14 months of which } \\
2 \text { months are } \\
\text { reserved for each } \\
\text { parent } \\
\text { Amount } \\
67 \% \text { of prior net } \\
\text { Income for } \\
\text { prevlously } \\
\text { employed, } \\
\text { e3o0 per month for } \\
\text { prevlously not } \\
\text { employed }\end{array}$ & Maximum amount: $e 1,800$ & $\begin{array}{l}\text { Parental leave may be taken up to } \\
\text { the chlldrs } 8^{*} \text { birthday; however, } \\
\text { parental leave benefits are provided } \\
\text { up to } 14 \text { months atter childbirth only. }\end{array}$ \\
\hline 2011 & No change & $\begin{array}{l}\text { Change In amount: } \\
65-67 \% \text { of prior net } \\
\text { Income for } \\
\text { prevlously } \\
\text { employed, } \\
\text { depending on level } \\
\text { of income }\end{array}$ & $\begin{array}{l}\text { Couples with a household income } \\
\text { of more than } 6500,000 \text { are not } \\
\text { ellglble. }\end{array}$ & No change \\
\hline
\end{tabular}




\section{Tables \& Figures}

Table 1. Composition of the Sample by Year of Birth of Child, Column \%

\begin{tabular}{|c|c|c|c|}
\hline & \multicolumn{2}{|c|}{ Year of birth of child } & \multirow[b]{2}{*}{ Total } \\
\hline & 1996-2006 & $2007-2012$ & \\
\hline \multicolumn{4}{|l|}{ Region } \\
\hline Western Germany & 87.5 & 84.3 & 86.5 \\
\hline Eastern Germany & 12.5 & 15.7 & 13.5 \\
\hline \multicolumn{4}{|l|}{ Citizenship } \\
\hline German & 86.5 & 88.2 & 87.0 \\
\hline Non-German & 13.5 & 11.8 & 13.0 \\
\hline \multicolumn{4}{|l|}{ Age of respondent } \\
\hline Age $18-25$ & 5.0 & 4.5 & 4.9 \\
\hline Age 26-30 & 18.7 & 17.8 & 18.4 \\
\hline Age 31-35 & 35.3 & 31.0 & 34.0 \\
\hline Age $36-40$ & 27.6 & 27.5 & 27.5 \\
\hline Age $41-45$ & 10.1 & 14.4 & 11.4 \\
\hline Age 46-55 & 3.4 & 4.8 & 3.8 \\
\hline \multicolumn{4}{|l|}{ Partnership status } \\
\hline Married & 88.4 & 82.0 & 86.4 \\
\hline Cohabiting & 11.6 & 18.0 & 13.6 \\
\hline \multicolumn{4}{|l|}{ Age of youngest child } \\
\hline Age 0 & 31.1 & 42.4 & 34.6 \\
\hline Age 1 & 35.0 & 33.9 & 34.7 \\
\hline Age 2 & 33.8 & 23.7 & 30.7 \\
\hline \multicolumn{4}{|l|}{ Number of children } \\
\hline One child & 43.8 & 45.4 & 44.3 \\
\hline Two children & 40.0 & 38.2 & 39.4 \\
\hline Three or more children & 16.2 & 16.4 & 16.3 \\
\hline \multicolumn{4}{|l|}{ Education } \\
\hline No degree & 12.4 & 12.9 & 12.6 \\
\hline Vocational degree & 63.3 & 60.7 & 62.5 \\
\hline University & 21.0 & 26.0 & 22.5 \\
\hline $\mathrm{N} / \mathrm{a}$ & 3.3 & 0.4 & 2.4 \\
\hline \multicolumn{4}{|l|}{ Type of contract } \\
\hline Temporary & 7.2 & 8.6 & 7.7 \\
\hline Permanent & 79.6 & 77.9 & 79.0 \\
\hline Self-employed & 13.0 & 13.4 & 13.1 \\
\hline $\mathrm{N} / \mathrm{a}$ & 0.2 & 0.1 & 0.2 \\
\hline \multicolumn{4}{|l|}{ Sector of employment } \\
\hline Public & 13.0 & 12.0 & 12.7 \\
\hline Private & 87.0 & 88.0 & 87.3 \\
\hline \multicolumn{4}{|l|}{ Education \& partner's education } \\
\hline Both no degree & 8.0 & 7.1 & 7.7 \\
\hline Both vocational degree & 50.3 & 46.5 & 49.1 \\
\hline Both university degree & 10.1 & 15.3 & 11.7 \\
\hline Woman has lower education & 19.5 & 18.6 & 19.3 \\
\hline Woman has higher education & 7.7 & 12.0 & 9.0 \\
\hline $\mathrm{N} / \mathrm{a}$ & 4.3 & 0.6 & 3.2 \\
\hline Number of cases & 86,805 & 38,295 & 125,100 \\
\hline Number of fathers on parental leave & 449 & 756 & 1,205 \\
\hline
\end{tabular}

Source: Scientific-Use-File of the German microcensus 1999-2012. 
Table 2. Results from Logistic Regression Model, Average Predicted Probabilities (Av. Pr. Pr.), Dependent Variable: (1) Using Parental Leave (0) Not Using Parental Leave

\begin{tabular}{|c|c|c|c|c|c|c|}
\hline \multirow{3}{*}{ Birth year of child } & & \multicolumn{3}{|c|}{ Model 2} \\
\hline & \multicolumn{6}{|c|}{ Av. Pr. Pr. 95 \% Conf. Intervalıv. Pr. Pr. 95 \% Conf. Interval } \\
\hline & & & & & & \\
\hline 1996-2006 & 0.0055 & 0.0050 & 0.0060 & 0.0056 & 0.0051 & 0.0061 \\
\hline 2007-2012 & 0.0175 & 0.0163 & 0.0188 & 0.0168 & 0.0156 & 0.0180 \\
\hline \multicolumn{7}{|l|}{ Region (Ref. Western Germany) } \\
\hline Western Germany & 0.0093 & 0.0087 & 0.0098 & 0.0093 & 0.0087 & 0.0099 \\
\hline Eastern Germany & 0.0118 & 0.0101 & 0.0134 & 0.0115 & 0.0099 & 0.0130 \\
\hline \multicolumn{7}{|l|}{ Citizenship (Ref. German) } \\
\hline German & 0.0100 & 0.0094 & 0.0106 & 0.0100 & 0.0094 & 0.0106 \\
\hline Non-German & 0.0062 & 0.0048 & 0.0076 & 0.0063 & 0.0049 & 0.0077 \\
\hline \multicolumn{7}{|l|}{ Age of respondent (Ref. 31-35) } \\
\hline Age 18-25 & 0.0053 & 0.0036 & 0.0071 & 0.0060 & 0.0040 & 0.0079 \\
\hline Age 26-30 & 0.0064 & 0.0054 & 0.0075 & 0.0067 & 0.0057 & 0.0078 \\
\hline Age 31-35 & 0.0104 & 0.0094 & 0.0113 & 0.0103 & 0.0093 & 0.0112 \\
\hline Age 36-40 & 0.0102 & 0.0090 & 0.0113 & 0.0098 & 0.0088 & 0.0109 \\
\hline Age 41-45 & 0.0128 & 0.0109 & 0.0147 & 0.0123 & 0.0105 & 0.0142 \\
\hline Age $46-55$ & 0.0137 & 0.0103 & 0.0171 & 0.0137 & 0.0103 & 0.0171 \\
\hline \multicolumn{7}{|l|}{ Partnership status (Ref. Married) } \\
\hline Married & 0.0093 & 0.0087 & 0.0099 & 0.0093 & 0.0087 & 0.0099 \\
\hline Cohabiting & 0.0113 & 0.0098 & 0.0128 & 0.0113 & 0.0098 & 0.0128 \\
\hline \multicolumn{7}{|l|}{ Age of youngest child (Ref. Age 0) } \\
\hline Age 0 & 0.0151 & 0.0140 & 0.0163 & 0.0150 & 0.0139 & 0.0161 \\
\hline Age 1 & 0.0081 & 0.0073 & 0.0090 & 0.0082 & 0.0073 & 0.0090 \\
\hline Age 2 & 0.0043 & 0.0036 & 0.0050 & 0.0043 & 0.0037 & 0.0050 \\
\hline \multicolumn{7}{|l|}{$\begin{array}{l}\text { Number of children (Ref. One } \\
\text { child) }\end{array}$} \\
\hline One child & 0.0120 & 0.0111 & 0.0130 & 0.0117 & 0.0108 & 0.0126 \\
\hline Two children & 0.0083 & 0.0075 & 0.0091 & 0.0083 & 0.0075 & 0.0092 \\
\hline Three or more children & 0.0064 & 0.0053 & 0.0075 & 0.0069 & 0.0057 & 0.0080 \\
\hline \multicolumn{7}{|l|}{ Education (Ref. Vocational degree) } \\
\hline No degree & 0.0092 & 0.0074 & 0.0110 & & & \\
\hline Vocational degree & 0.0091 & 0.0084 & 0.0098 & & & \\
\hline University & 0.0111 & 0.0099 & 0.0122 & & & \\
\hline \multicolumn{7}{|l|}{ Type of contract (Ref. Permanent) } \\
\hline Temporary & 0.0057 & 0.0042 & 0.0072 & 0.0055 & 0.0041 & 0.0069 \\
\hline Permanent & 0.0107 & 0.0100 & 0.0113 & 0.0108 & 0.0101 & 0.0114 \\
\hline Self-employed & 0.0059 & 0.0047 & 0.0071 & 0.0056 & 0.0045 & 0.0068 \\
\hline \multicolumn{7}{|l|}{ Type of sector (Ref. Private) } \\
\hline Public & 0.0134 & 0.0116 & 0.0152 & 0.0131 & 0.0113 & 0.0148 \\
\hline Private & 0.0090 & 0.0085 & 0.0096 & 0.0091 & 0.0085 & 0.0096 \\
\hline \multicolumn{7}{|l|}{$\begin{array}{l}\text { Education \& Partner's education } \\
\text { (Ref. Both vocational degree) }\end{array}$} \\
\hline Both no degree & & & & 0.0054 & 0.0036 & 0.0072 \\
\hline Both vocational degree & & & & 0.0084 & 0.0077 & 0.0091 \\
\hline Both university degree & & & & 0.0144 & 0.0126 & 0.0162 \\
\hline Woman has lower education & & & & 0.0065 & 0.0055 & 0.0075 \\
\hline Woman has higher education & & & & 0.0173 & 0.0150 & 0.0196 \\
\hline \multicolumn{7}{|l|}{ Model summary } \\
\hline Log likelihood starting model & & $-6,794$ & & & $-6,794$ & \\
\hline Log likelihood & & $-6,263$ & & & $-6,193$ & \\
\hline Pseudo $\mathrm{R}^{2}$ & & 0.078 & & & 0.0885 & \\
\hline Number of cases & & 125,100 & & & 125,100 & \\
\hline Number of fathers on parental leave & & 1,205 & & & 1,205 & \\
\hline
\end{tabular}

Notes: Controlled for missing values in the variables "type of contract”, "education” and "education \& partner's education”.

Source: see table 1. 
Figure 1. Results from Logistic Regression Model, Average Predicted Probabilities,

Dependent Variable: (1) Using Parental Leave (0) Not Using Parental Leave, Interaction of Child's Year of Birth and Education

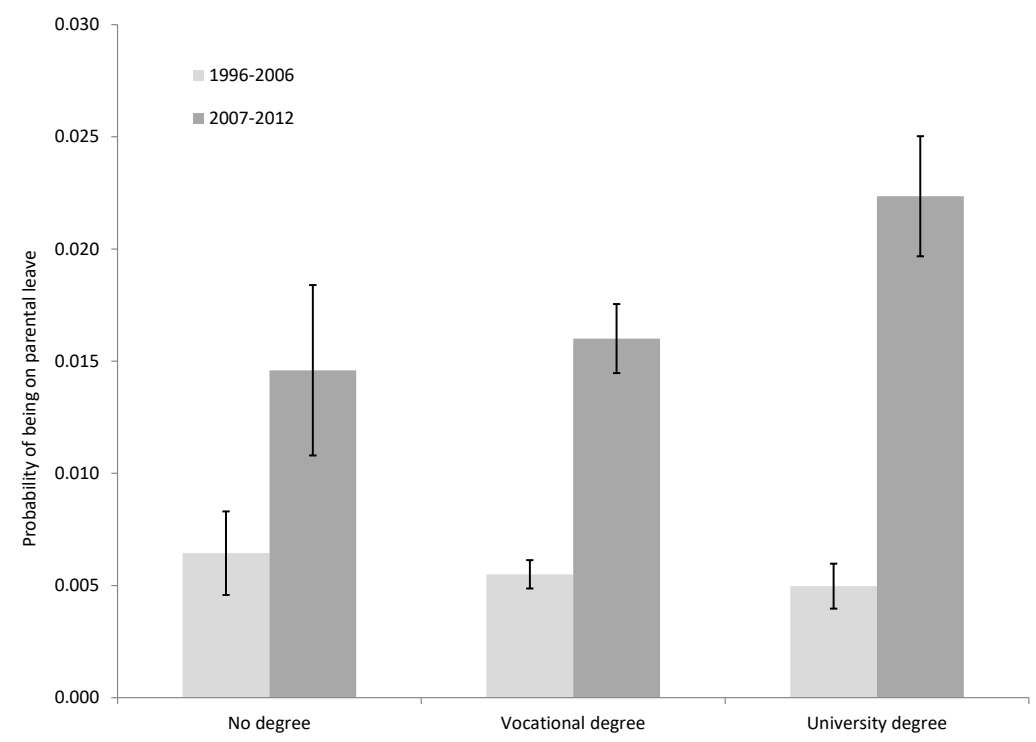

Notes: Controlled for: region, citizenship, age of respondent, partnership status, age of youngest child, number of children, type of contract, type of sector.

Source: see table 1. 
Figure 2. Results from Logistic Regression Model, Average Predicted Probabilities, Dependent Variable: (1) Using Parental Leave (0) Not Using Parental Leave, Interaction of Child's Year of Birth and Relative Education

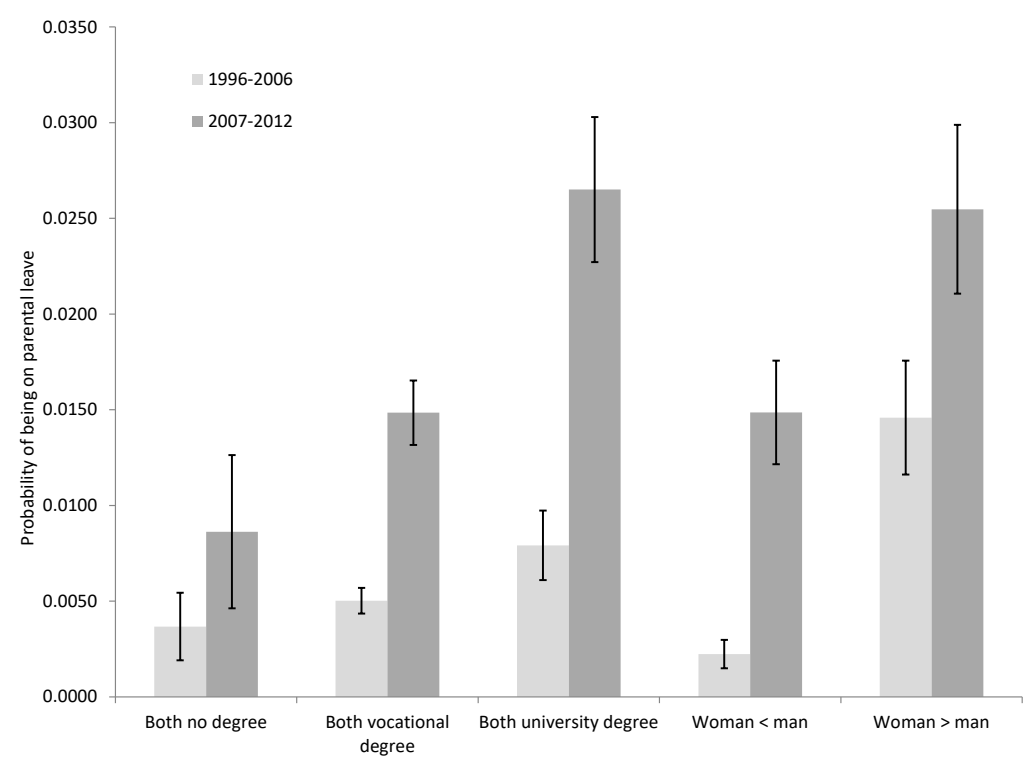

Notes: Controlled for: region, citizenship, age of respondent, partnership status, age of youngest child, number of children, type of contract, type of sector.

Source: see table 1. 
Figure 3. Results from Logistic Regression Model, Average Predicted Probabilities, Dependent Variable: (1) Using Parental Leave (0) Not Using Parental Leave, Interaction of Child's Year of Birth and Type of Contract

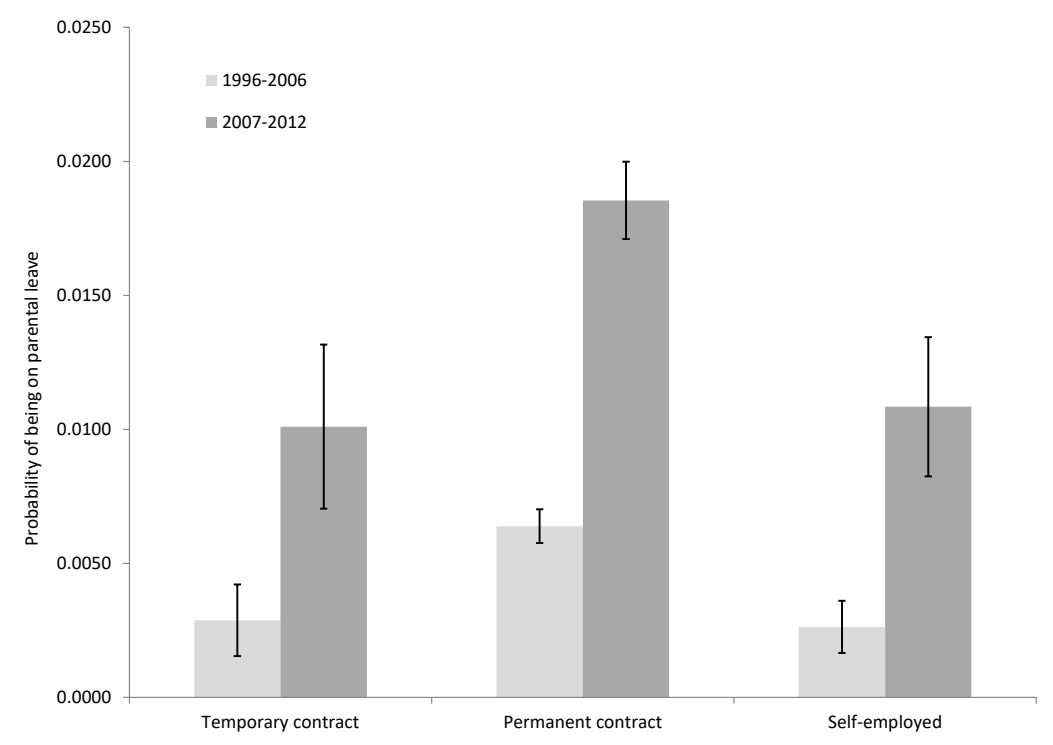

Notes: Controlled for: region, citizenship, age of respondent, partnership status, age of youngest child, number of children, education \& partner's education, type of sector.

Source: see table 1. 
Figure 4. Results from Logistic Regression Model, Average Predicted Probabilities, Dependent Variable: (1) Using Parental Leave (0) Not Using Parental Leave, Interaction of Child's Year of Birth and Sector of Employment

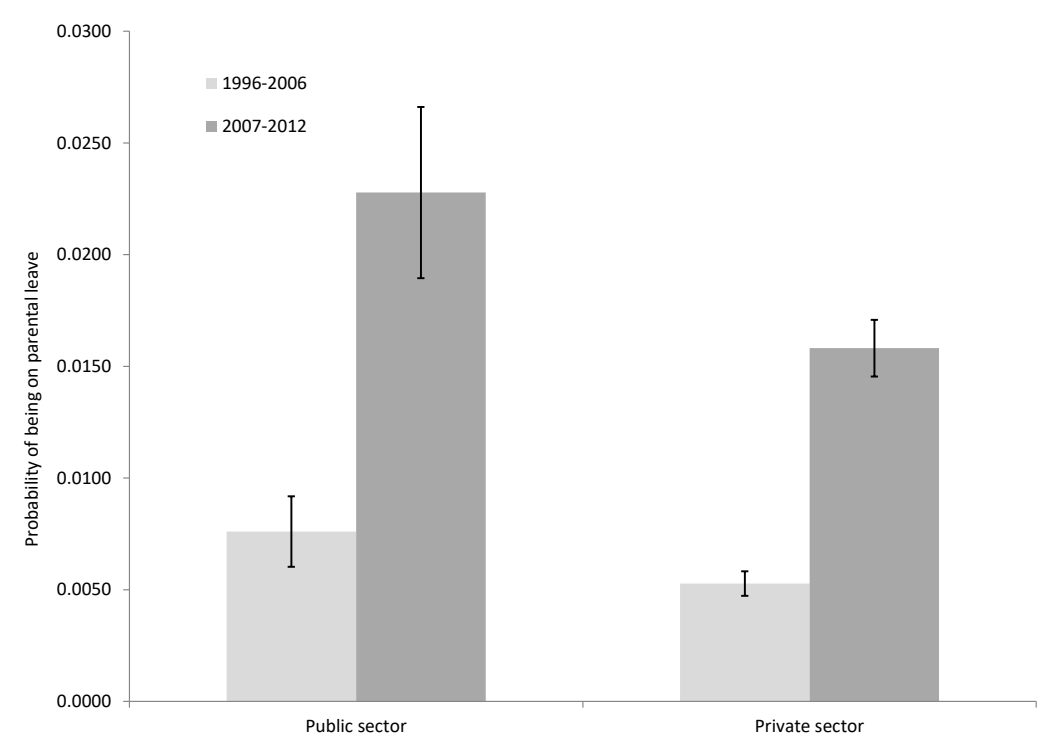

Notes: Controlled for: region, citizenship, age of respondent, partnership status, age of youngest child, number of children, education \& partner's education, type of contract Source: see table 1. 